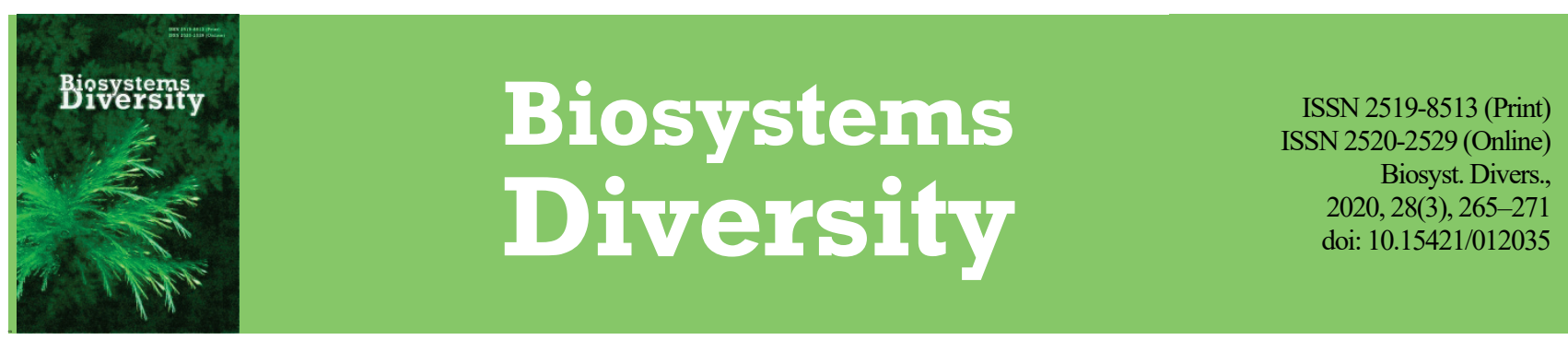

\title{
The ground beetles (Coleoptera, Carabidae) of the Karatepa and Chakilkalyan mountains (west part of Zarafshan Mountains Range, Uzbekistan)
}

\author{
F. Khalimov
}

\author{
Samarkand State University, Samarkand, Uzbekistan
}

Article info

Received 05.07.2020

Received in revised form 10.08.2020

Accepted 12.08.2020

Samarkand State

University,

University Boulevard, 15

Samarkand, 140100 ,

Uzbekistan.

Tel.: +99-897-925-95-98.

E-mail:

xalimov1968@list.ru

\section{Khalimov, F. (2020). The ground beetles (Coleoptera, Carabidae) of the Karatepa and Chakilkalyan mountains (west part of Zarafshan Mountains Range, Uzbekistan). Biosystems Diversity, 28(3), 265-271. doi:10.15421/012035}

Ground beetles (Carabidae) are one the most numerous and well-studied families of Coleoptera. However, the study of the biodiversity of these beetles in Uzbekistan lags far behind other Central Asian countries. This research was carried out during 2018-2019 in two areas in the west part of the Zarafshan Mountain Range - in the Chakilkalyan and Karatepa mountains. In total, 49 species of ground beetles belonging to 31 genera, 16 tribes and 8 subfamilies were recorded. The most representative was the subfamily Harpalinae (32 species from 20 genera, 65.3\%). By the number of individuals, representatives of Harpalinae made up $85.6 \%$ of all collected ground beetles. The Trechinae subfamily included five species from three genera $(10.2 \%)$, the Scaritinae subfamily - four species from two genera $(8.2 \%)$, the Carabinae subfamily - three species from two genera $(6.1 \%)$, the Broscinae subfamily - two species from the same genus (4.1\%). The subfamilies Brachininae, Cicindelinae and Nebriinae are represented by one species ( $2.0 \%$ each). In the Karatepa Mountains, 34 species from 23 genera were identified, and in the Chakilkalyan Mountains, 34 species from 21 genera. 19 species of ground beetles were common to the two mountains. The fauna of ground beetles in these mountains differed significantly in the composition of the dominant species. In the Karatepa Mountains, the dominant species were Zabrus morio, Eocarterus chodshenticus, Amara aenea, and Acinopus laevigatus, and the subdominant ones were Brachinus explodens, Calathus ambiguus, and Poecilus longiventris. In the Chakilkalyan Mountains, Anchomenus dorsalis, Harpalus rufipes, and Chlaenius extensus are dominant, while Amara aenea, Harpalus distinguendus, Dolichus halensis turned out to be subdominant. However, the composition of dominant species varied at different sites. The rarest species were Anisodactylus binotatus, Cymindis andreae, Taphoxenus goliath, Calosoma sycophanta, Scarites subcylindricus, Chilotomusus gentensis, Calathus peltatus and Broscus punctatus. Different areas of both mountains differed significantly in the diversity of ground beetle fauna. In both mountains, the lowest diversity was noted at the highest altitude areas. In four areas of the Karatepa Mountains, the average value of the Zhakar and Chekanovsky-Sørensen indices was 0.27 and 0.11 , and in five areas of the Chakilkalyan Mountains -0.24 and 0.25 . And the similarities between the communities of the two mountains were also insignificant $(0.39$ and 0.11$)$

Keywords: degree of dominance; faunal peculiarities; species composition; Cicindelinae; Carabinae; Harpalinae; Trechinae; Brachininae; Nebriinae.

\section{Introduction}

Ground beetles are a very large and diverse taxon among Coleoptera, and about 100 new species are discovered every year (Lorenz, 2005; Kotze et al., 2011). They are an important link in food chains and play a huge role in energy transformation (Skalski et al., 2011; Schirmel et al., 2012). They are sensitive to environmental changes, exhibiting strong habitat specificity and low ability to spread rapidly to neighbouring areas (Work et al., 2008). Therefore, ground beetles have been widely used to compare the ecology of pristine forests and artificial plantations (Finch, 2005), in the environmental monitoring of post-industrial ecosystems (Skalski et al., 2015; Bell et al., 2017; Kędzior, 2020). Many carabid species, as universal predators with a wide food spectrum, can enter as an important component of biological regulation (Symondson et al., 2002; Stiling \& Cornelissen, 2005).

The works of Kryzhanovskij (1965) are of great importance in the study of the carabid fauna of Central Asia. As he argued, the fauna of the ground beetles of Central Asia is very diverse and includes more than 850 species, and is also characterized by many endemic forms. In subsequent works, the list of the species composition of ground beetles in this region has been significantly expanded (Kryzhanovskij et al., 1995; Mihaylov, 1995, 1998). Thus, in the Tien Shan mountain system, within the republics of Kazakhstan, Kyrgyzstan, Tajikistan and Uzbekistan, 819 species of ground beetles were recorded (Kryzhanovskij et al., 1995). On these mountains, there are 114 species of representatives of the genus Carabus alone (Kabak, 2008). And the fauna of ground beetles of the Pamir-Alai mountain system, located in the southeastern part of Central Asia, is less diverse and includes 510 species (Kryzhanovskij et al., 1995). However, the registration of ground beetle species new to the region continues at the present time (Kabak, 2015; Kabak et al., 2016).

Although the registered species of ground beetles in Uzbekistan reaches 453 species (http://carabidae.org/countries.2007-2020), the study of the ecological faunistic features of ground beetles in this region, especially in the Zarafshan Valley, is clearly insufficient.

The very steep, narrow and snow-covered Zarafshan ridge is characterized by an abundance of rocky outcrops, ruggedness, steepness of the slopes, and the presence of sharp peaks. Within Uzbekistan, the western part of the ridge serves as a watershed of the river basins of Zarafshan and Kashkadarya.

The Zarafshan Ridge on the territory of Uzbekistan is divided into four parts: the Chakilkalyan, Karatepa, Zirabulak and Ziadin mountains. The Chakilkalyan Mountains, the eastern part of the Zarafshan Range within Uzbekistan, continue to the Takhtakaracha Pass. The height of the pass is $1630 \mathrm{~m}$. The average height of the Chakilkalyan Mountains is 1000-2000 m, The Karatepa Mountains extend to the west of the Chakilkalyan Mountains (the highest point is Kamkutan Peak 2194 m, average altitude 1000-2000 m), which are mainly low-altitude (Zhumaev, 1989).

Invertebrate animals, in particular, beetles of these mountains, have a wide variety. However, directed scientific research on the study of the biodiversity of beetles, in particular, ground beetles in the studied territo- 
ries, has not been carried out. There are studies on individual groups of ground beetles in other Central Asian republics (Kryzhanovsky, 1965, 1994; Kabak, 2015). Furthermore, the data on the territory of Uzbekistan is outdated, and the new data is mainly based on museum exhibits. In general, ground beetles of Uzbekistan have been more or less studied in agrocenoses of cotton (Dadamirzaev, 1978; Bekmetova, 1991) and vegetable crops (Khalimov, 2008) as entomophages of agricultural pests.

Information about ground beetles of the Zarafshan Valley can be found in faunistic works (Alimjanov \& Bronstein, 1956) or for the southern slopes of the Zarafshan Ridge located on the territory of Tajikistan (Mihaylov, 1998).

Our research aimed to study the species diversity and taxonomic composition of ground beetles of the Chakilkalyan and Karatepa mountains of the Zarafshan Ridge, located on the territory of Uzbekistan.

\section{Material and Methods}

The studies were conducted in the period 2018-2019 in the territories of the Chakilkalyan and Karatepa mountains, as well as in the foothill zones. The Karatepa Mountains are bordered on the east by the Chakilkalyan Mountains and join the Zirabulak Mountains. In this direction, the height of the mountains above sea level also decreases. According to the direction of the mountains, 4 areas were selected for the study: Takhtako-

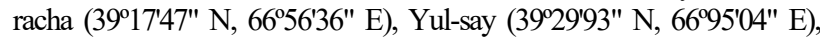
Ettiuyli-say (39 $43^{\prime} 42^{\prime \prime} \mathrm{N}, 66^{\circ} 98^{\prime} 25^{\prime \prime}$ E) and Agalik-say (39 $29^{\prime} 26^{\prime \prime} \mathrm{N}$,
6651'46" E). All selected sites are characterized by meadow vegetation with a scattering of tree species. Artificially created forest biotopes prevailed only on the Ettiuili-say site.

From the south, the Chakilkalyan Mountains starts from the border of Uzbekistan with Tajikistan (Pejikent Province) and continues to the northwest $60-70 \mathrm{~km}$ to the Karatepa Mountains. Five sites were selected for research, one of which is on the southern slope (Hazrat Bashir, (39 $15^{\prime} 58^{\prime \prime}$ $\mathrm{N}, 67^{\circ} 07^{\prime} 00^{\prime \prime} \mathrm{E}$ ), and the other four are on the northern slope (Yalpoqtepa-

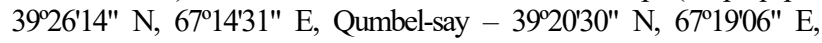

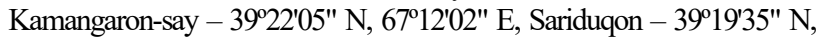
$67^{\circ} 13^{\prime} 48^{\prime \prime}$ E). One site (Yalpoqtepa) is a cultivated landscape (vineyards). The Chakilkalyan Mountains differ from the Karatepa Mountains by the absence or scarcity of forest vegetation (except for the Kamangaron-say site).

In 2018, three expeditions were organized at each site (April, May, September), and in 2019, four expeditions (March, April, May, August). In order to collect beetles, soil traps of the Barber - Heideman type (Barber, 1931; Heydemann, 1955), light traps, exhauster, and manual collection were used. Glass jars (Karpova, 1992) with a capacity of $0.5 \mathrm{~L}$ and a hole diameter of $72 \mathrm{~mm}$ were used as traps (the jars were buried in the soil so that the edges were at the level of the soil) installed in a line of 10 traps at a distance of $5 \mathrm{~m}$ from each other. Some of the traps were without a retainer, and some with a fixing liquid. As a fixative, a $4 \%$ formalin solution was used, which filled soil traps in $1 / 3-1 / 2$ volumes. Traps were sampled once every 10-12 days. Collected beetles were identified by species, counted and compiled.

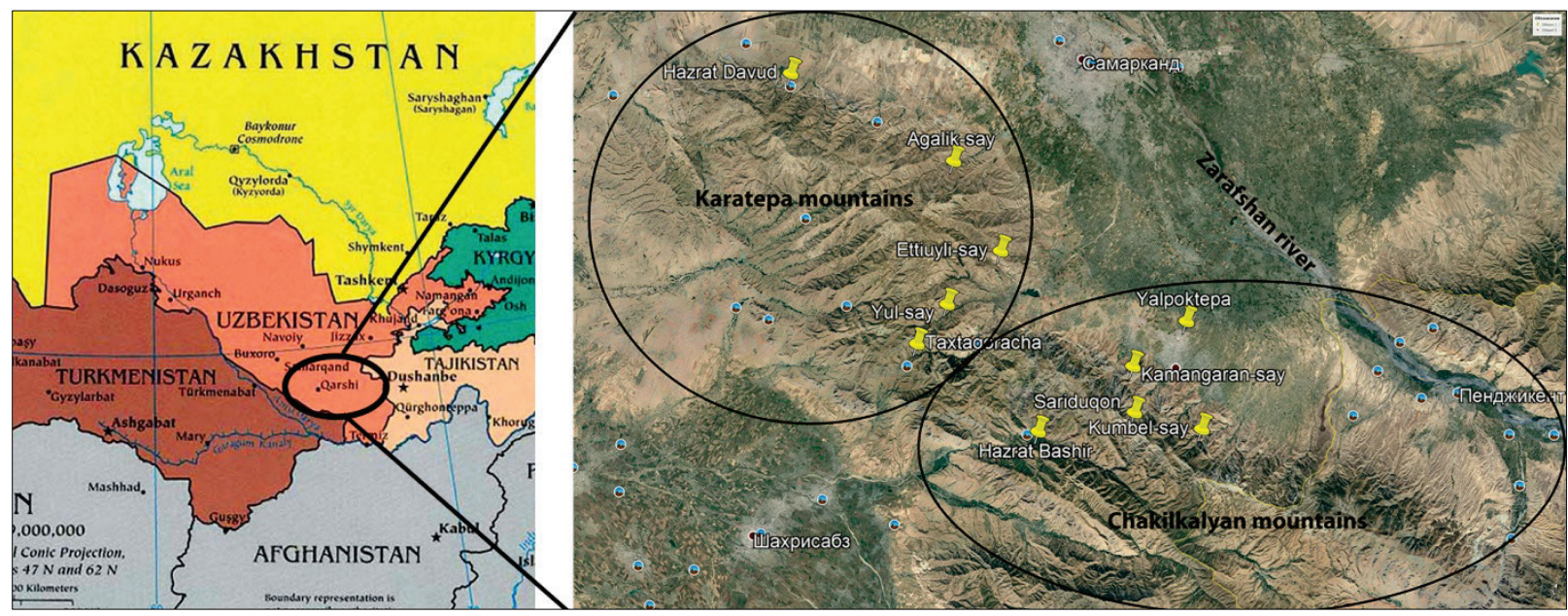

Fig. 1. Research Area Map (places of collection of material)

The degree of dominance was determined on the Skufin scale (Skufin, 1949), where more than $8 \%$ are dominant species, from $4 \%$ to $8 \%$ subdominant species, $1-3 \%$ are scarce species. Statistical calculations of biodiversity were carried out according to the guidance of Dunaev (1997):

- Margalef index $-\mathrm{D}_{\mathrm{Mg}}=(\mathrm{S}-1) / \mathrm{lnN}$, where $\mathrm{S}$ is the number of identified species, $\mathrm{N}$ is the total number of individuals of all identified species, $\ln$ is the natural logarithm;

- Shannon's index $-H^{\prime}=-\Sigma p_{i} l n p_{i}$, where $p_{i}$ is the proportion of individuals of the $\mathrm{i}-$ the species;

- Menhinick index $-D_{M n}=S / \sqrt{ } N$, where $S$ is the total number of identified species, $\mathrm{N}$ is the total number of individuals of all species;

- Shannon alignment $-\mathrm{E}=\mathrm{H}^{\prime} / \mathrm{lnS}$, where $\mathrm{H}^{\prime}$ is the Shannon index, $\mathrm{S}$ is the number of species;

- Simpson index $-\mathrm{D}\left(\mathrm{S}_{\lambda}\right)=\Sigma\left(\mathrm{n}_{\mathrm{i}}\left(\mathrm{n}_{\mathrm{i}}-1\right)\right) / \mathrm{N}(\mathrm{N}-1)$, where $\mathrm{n}$ is the number of individuals of $\mathrm{i}$ species, $\mathrm{N}$ is the total number of individuals;

- Berger-Parker index $-\mathrm{d}=\mathrm{N}_{\max } / \mathrm{N}$, where $\mathrm{N}_{\max }$ is the number of individuals of the most abundant species, $\mathrm{N}$ is the total number of individuals of all species of the sample;

- Chekanovsky-Sørensen coefficient $-\mathrm{CN}=2 \mathrm{jN} /(\mathrm{aN}+\mathrm{bN})$, where $\mathrm{aN}+\mathrm{bN}$ is the total number of individuals in sites $\mathrm{A}$ and $\mathrm{B}, \mathrm{jN}$ is the smallest of the two abundance of species found in both sites;

- Jaccard coefficient: $C_{j}=j /(a+b-j)$, where $j$ is the number of common species in both territories (sites, samples), and $b$ is the number of species in each territory (sites, samples).
The compiled collection of ground beetles is stored in the Entomological Collection of Samarkand University, as well as in the Zoological Museum of the Institute for Systematics and Ecology of Animals of the Siberian Branch of the Russian Academy of Sciences (Russia).

\section{Results}

Taxonomic composition. Over the years of research in the two parts of the Zarafshan Ridge (Karatepa and Chakilkalyan mountains), 49 species of ground beetles were identified, belonging to 31 genera, 16 tribes and 8 subfamilies (Table 1). The most representative in terms of the number of species is the subfamily Harpalinae, which includes 32 species (65.3\% of the total species diversity). In terms of the number of individuals, the subfamily Harpalinae makes up $85.6 \%$ of all collected ground beetles. Among the representatives of this subfamily, the tribe Harpalini has the largest number of species, which is represented by 12 species from 8 genera (genus Harpalus - 4 species, Dixus - 2 species, Acinopus, Anisodactylus, Chilotomus, Carenochyrus, Eocarterus and Stenolophus - one species each). Numerous representatives of these genera are Acinopus laevigatus, Eocarterus chodshenticus, Harpalus rufipes, and Dixus eremita.

The tribe Sphodrini is represented by 5 species from 3 genera (Taphoxenus and Dolichus - one species each and Calathus - 3 species), the most abundant representative of which is Calathus ambiguus. The tribe Pterostichini is also represented by 5 species from two genera 
(Pterostichus niger and Poecilus -4 species). Three species of the tribe Chlaeniini, belonging to the genus Chlaenius, have been identified. The most common is Chlaenius extensus. The tribe Zabrini also has three representatives (two species from the genus Amara and one species from the genus Zabrus). Amara aenea and Zabrus morio are dominant species of the carabid fauna of the studied mountains. The tribes Lebiini (genus Lebia and Cymindis) and Platynini (genus Agonum and Anchomenus) are represented by two species.

Table 1

Taxonomic composition of ground beetles of the Karatepa and Chakilkalyan mountains of Uzbekistan

\begin{tabular}{|c|c|c|c|c|c|}
\hline Subfamily & Tribe & Species & Mt. Karatepa & Mt. Chakilkalyan & Share of species, $\%$ \\
\hline Nebriinae & Nebriini & Nebria psammophila Solsky, 1874 & - & + & 0.7 \\
\hline \multirow[t]{3}{*}{ Carabinae } & Carabini & Calosoma auropunctatum dzungaricum Gilber, 1833 & - & + & 0.8 \\
\hline & & C. sycophanta (Linnaeus, 1758) & + & - & 0.2 \\
\hline & & Carabus fedtschenkoi Solsky, 1874 & + & - & 1.8 \\
\hline Cicindelinae & Cicindelini & Cicindela turkestanica Ballion, 1871 & + & - & 1.7 \\
\hline \multirow[t]{4}{*}{ Scaritinae } & Scaritini & Scarites basiplicatus Heyden, 1884 & + & + & 1.0 \\
\hline & & S. terricola Bonelli, 1813 & + & + & 1.0 \\
\hline & & S. subcylindricus Chaudoir, 1843 & + & - & 0.2 \\
\hline & Clivinini & Clivina collaris Herbst, 1784 & + & - & 0.3 \\
\hline \multirow[t]{2}{*}{ Broscinae } & Broscini & Broscus punctatus (Dejean, 1828) & - & + & 0.2 \\
\hline & & B. asiaticus Ballion, 1871 & - & + & 5.3 \\
\hline \multirow[t]{5}{*}{ Trechinae } & Bembidiini & Asaphidion flavicorne(Solsky, 1874) & - & + & 0.5 \\
\hline & & Bembidion piceocyaneum Solsky, 1874 & - & + & 0.3 \\
\hline & & B.luridicorne Solsky, 1874 & + & + & 1.3 \\
\hline & & B. saxatile flavipalpe Netolitzky, 1930 & - & + & 0.5 \\
\hline & Trechini & Trechus quadristriatus(Schrank,1781) & + & + & 1.8 \\
\hline Brachininae & Brachinini & Brachinus explodens Duftschmid, 1812 & + & + & 1.3 \\
\hline \multirow[t]{32}{*}{ Harpalinae } & Chlaeniini & Chlaenius flavicornis(Fischer von Waldheim, 1842) & + & + & 1.1 \\
\hline & & Ch. extensus Mannerheim, 1825 & + & + & 4.9 \\
\hline & & Ch. festivus (Panzer, 1796) & + & + & 0.3 \\
\hline & Harpalini & Acinopus laevigatus Menetries, 1832 & + & + & 7.7 \\
\hline & & Anisodactylus binotatus (Fabricius, 1787) & + & - & 0.2 \\
\hline & & Chilotomusus gentensis Schauberger, 1932 & + & - & 0.3 \\
\hline & & Carenochyrus titanus Solsky,1874 & - & + & 0.7 \\
\hline & & Dixus eremita Dejean, 1825 & + & + & 3.5 \\
\hline & & D. semicylindricus Piochard de la Brûlerie, 1872 & + & - & 0.5 \\
\hline & & Eocarterus chodshenticus (Ballion, 1871) & + & + & 10.0 \\
\hline & & Harpalus rufipes (De Geer, 1774) & - & + & 3.3 \\
\hline & & H. griseus (Panzer, 1796) & + & + & 0.3 \\
\hline & & H. distinguendus (Duftschmid, 1812) & - & + & 2.5 \\
\hline & & H. rubripes (Duftschmid, 1812) & - & + & 0.7 \\
\hline & & Stenolophus abdominalis Gené, 1836 & + & + & 0.3 \\
\hline & Lebiini & Lebia cyanocephala Linnaeus, 1758 & + & - & 1.5 \\
\hline & & Cymindis andreae Ménétriés, 1832 & + & - & 0.2 \\
\hline & Platynini & Agonum viridicupreum (Goeze, 1777) & + & - & 0.3 \\
\hline & & Anchomenus dorsalis (Pontoppidan, 1763) & + & + & 5.3 \\
\hline & Pterostichini & Pterostichus niger (Schaller, 1783) & - & + & 0.8 \\
\hline & & Poecilus cupreus (Linnaeus,1758) & + & + & 2.8 \\
\hline & & P. liosomus Chaudoir,1876 & + & + & 2.8 \\
\hline & & P. longiventris Solsky, 1874 & + & - & 1.3 \\
\hline & & P.sp. & + & - & 0.2 \\
\hline & Sphodrini & Calathus ambiguus (Paykull, 1790) & + & + & 5.9 \\
\hline & & C. peltatus Kolenati, 1845 & - & + & 0.2 \\
\hline & & C. melanocephalus (Linnaeus, 1758) & + & + & 0.5 \\
\hline & & Dolichus halensis (Schaller, 1783) & - & + & 1.8 \\
\hline & & Taphoxemus goliath (Faldermann, 1836) & + & - & 0.2 \\
\hline & Zabrini & Amara similata (Gyllenhal,1810) & - & + & 0.3 \\
\hline & & A. aenea (De Geer,1774) & + & + & 11.0 \\
\hline & & Zabrus morio Ménétriés, 1832 & + & - & 9.7 \\
\hline 8 & 16 & 49 & 34 & 34 & 100.0 \\
\hline
\end{tabular}

In the carabid complex of the studied mountains from small ground beetles of the subfamily Trechinae, there are five species from two tribes and three genera. The Trechini tribe is represented only by Trechus quadristriatus, and the Bembidiini tribe includes 4 species (the Asaphidion genus - one species, the Bembidion genus - three species). Although in anthropogenic landscapes these species are widespread and numerous, in the studied mountains their number is low. In general, representatives of the subfamily Trechinae account for $4.4 \%$ of all individuals of ground beetles. Four species of beetles from the subfamily Scaritinae belonging to the genera Scarites (three species) and Clivina (one species) have been identified. The subfamily Carabinae is represented by three species of two genera (genus Carabus - one species, genus Calosoma two species). The Broscinae subfamily is represented by two species from the genus Broscus. The most abundant is Broscus asiaticus.

The subfamilies Brachininae, Cicindelinae, and Nebriinae are the only species in the complex of ground beetles in the studied territories.

Amara aenea, Eocarterus chodshenticus, and Zabrus morio are the dominant species in the Chakilkalyan and Karatepa Mountains, while 
Acinopus laevigatus, Calathus ambiguus, Broscus asiaticus, Anchomenus dorsalis and Chlaenius extensus are subdominant species.

Among the few species, several species can be distinguished, which, in terms of the degree of dominance, are close to subdominant species. These are Dixus eremita and Harpalus rufipes. 27 species of ground beetles, the dominance of which is less than $1 \%$, together account for $11.5 \%$ of the total carabid fauna.

The only rare specimens in our collections are Anisodactylus binotatus, Cymindis andreae, Taphoxenus goliath, Calosoma sycophanta, Scarites subcylindricus (Ettiuili-say Gorge) and Chilotomus usgentensis (Yul-say Gorge) from the Karatepa Mountains, Calathus peltatus (Kumbel-say gorge), Broscus punctatus (Kamangaron-say) from the Chakilkalyan Mountains.

Diversity in the Karatepa Mountains. As studies show, the fauna of ground beetles of the Karatepa Mountains includes 34 species belonging to 6 subfamilies and 23 genera (Table 2). The highest diversity was recorded in the Ettiuyli-say gorge, which is the middle part of the mountain
(27 species), and the lowest diversity was observed in the upper part of the mountain, Takhtakoracha (8 species).

Among the identified species only Eocarterus chodshenticus, Poecilus liosomus, and Cicindela turkestanica were noted in all study sites. The dominant species of ground beetles of the Karatepa Mountains are Zabrus morio (14.8\%), Eocarterus chodshenticus (13.6\%), Amara aenea (13.1\%), and Acinopus laevigatus (9.8\%) and the degree of their dominance is quite high. Although Zabrus morio is the most abundant species, this species was not recorded in the highest $(1550 \mathrm{~m}$ a. s. 1.) site of Takhtakoracha, and its abundance increases with decreasing altitude. The same tendency is observed in relation to Amara aenea, as this species is noted and quite numerous in the Ettiuyli-say and Agalik-say areas. As for Eocarterus chodshenticus, on the contrary, its population grows with increasing altitude. Although this species is common in all study sites, it is the most numerous at the Takhtakoracha site. The Takhtakoracha site has one specific species, Agonum viridicupreum, which has not been recorded in other sites.

Table 2

Diversity and abundance of Carabidae in four mountain areas on Mt. Karatepa

\begin{tabular}{|c|c|c|c|c|c|c|}
\hline \multirow[b]{2}{*}{ Species } & \multicolumn{4}{|c|}{ Montane habitat types } & \multirow[b]{2}{*}{ Total } & \multirow{2}{*}{$\begin{array}{c}\text { Share } \\
\text { of species, \% }\end{array}$} \\
\hline & $\begin{array}{c}\text { Taxtaqoracha } \\
(1550 \text { ma. s. } 1 .)\end{array}$ & $\begin{array}{c}\text { Yul-say } \\
\text { (1221 ma. s. 1.) }\end{array}$ & $\begin{array}{c}\text { Ettiuyli-say } \\
\text { (1059 ma. s. 1.) }\end{array}$ & $\begin{array}{c}\text { Agalik-say } \\
(1070 \text { ma. s. 1.) }\end{array}$ & & \\
\hline Acinopus laevigatus & - & 8 & 31 & - & 39 & 9.8 \\
\hline Agonum viridicupreum & 2 & - & - & - & 2 & 0.5 \\
\hline Amara aenea & - & - & 43 & 9 & 52 & 13.1 \\
\hline Anchomenus dorsalis & - & - & 5 & 3 & 8 & 2.0 \\
\hline Anisodactylus binotatus & - & - & 1 & - & 1 & 0.2 \\
\hline Bembidion luridicorne & 1 & - & - & 2 & 3 & 0.7 \\
\hline Brachinus explodens & - & - & - & 28 & 28 & 7.0 \\
\hline Calathus ambiguus & - & - & 23 & 7 & 30 & 7.5 \\
\hline C. melanocephalus & - & - & 1 & - & 1 & 0.2 \\
\hline Calosoma sycophanta & - & - & 1 & - & 1 & 0.2 \\
\hline Carabus fedtschenkoi & - & 9 & 1 & 1 & 11 & 2.8 \\
\hline Chilotomusus gentensis & - & 1 & - & - & 1 & 0.2 \\
\hline Chlaenius festivus & - & - & - & 1 & 1 & 0.2 \\
\hline Ch.flavicornis & - & - & 5 & - & 5 & 1.3 \\
\hline Ch. extensus & - & - & 1 & 9 & 10 & 2.5 \\
\hline Cicindela turkestanica. & 3 & 2 & 2 & 3 & 10 & 2.5 \\
\hline Clivina collaris & - & - & 2 & - & 2 & 0.5 \\
\hline Cymindis andreae & - & - & 1 & - & 1 & 0.2 \\
\hline Dixus eremita & 1 & 1 & 11 & - & 13 & 3.3 \\
\hline D. semicylindricus & 1 & - & 2 & - & 3 & 0.7 \\
\hline Eocarterus chodshenticus & 37 & 8 & 4 & 5 & 54 & 13.6 \\
\hline Harpalus distinguendus & - & - & 1 & - & 1 & 0.3 \\
\hline Lebia cyonocephala & - & - & 9 & - & 9 & 2.3 \\
\hline Poecilus cupreus & - & 1 & - & 1 & 2 & 0.5 \\
\hline P. liosomus & 2 & 4 & 1 & 3 & 10 & 2.5 \\
\hline P. longiventris & - & 11 & 6 & - & 17 & 4.3 \\
\hline P.sp. & - & 6 & - & 2 & 8 & 2.0 \\
\hline Scarites basiplicatus & 3 & - & 1 & - & 4 & 1.0 \\
\hline S. terricola & - & - & 1 & - & 1 & 0.3 \\
\hline S. subcylindricus & - & - & 1 & - & 1 & 0.3 \\
\hline Stenolophus abdominalis persicus & - & - & 1 & - & 1 & 0.3 \\
\hline Taphoxenus goliath & - & - & 1 & - & 1 & 0.3 \\
\hline Trechus quadristriatus & - & - & 8 & - & 8 & 2.1 \\
\hline Zabrus morio & - & 1 & 51 & 7 & 59 & 14.8 \\
\hline Number of individuals & 50 & 52 & 215 & 81 & 398 & 100.0 \\
\hline Number of species & 8 & 11 & 27 & 14 & 34 & - \\
\hline Species richness, Dmg & 1.79 & 2.53 & 4.84 & 2.96 & 5.53 & - \\
\hline Diversity indicator Shannon, $\mathrm{H}$ & 1.05 & 2.08 & 2.39 & 2.16 & 2.79 & - \\
\hline Berger-Parker dominance index, $\mathrm{d}$ & 0.74 & 0.21 & 0.24 & 0.35 & 0.15 & - \\
\hline
\end{tabular}

Chilotomus usgenetensis is a specific species in Yul-say (1221 m a. s. 1.) territory, and it couldn't be found in other researched areas. The rather large-sized species Carabus fedtschenkoi is quite abundant in this area, but in other areas this species is scarce and not recorded in the highest area (Takhtakoracha). The greatest species diversity of the carabid fauna was noted in the area with a predominance of forest biotopes - Ettiuyli-say. Here, along with the aforementioned dominant species (except for Eocarterus chodshenticus), Dixus eremita, Calathus ambiguus, and Lebia cyonocephala are abundant. The fauna of ground beetles in the northern part of the Karatepa Mountains, the Agalik-say section, is peculiar. The most abundant species in this site is Brachinus explodens, which makes up $34.6 \%$ of all collected ground beetles. However, this species was not observed in other areas (Table 1). In addition, no species of the genus Dixus (D. eremita, D. semicylindricus) were found in this area, and Chlaenius extensus is among the dominant species. Another species of this genus, Ch. festivus, was also noted, which was not found in other areas.

Comparative analysis of the species composition of ground beetles in the studied areas shows a rather low level of similarity (Table 3 ). Thus, the Jaccard/Chekanovsky-Sørensen indices varied from $0.21 / 0.06$ to $0.39 / 0.17$ (with an average value of only $0.27 / 0.11$ ). The greatest similarity is observed between the Yul-say and Agalik-say sections (0.39/0.17), and the least similarity is between Ettiuyli-say and Takhtakorach $(0.21 / 0.06)$. 
Table 3

Similarity of the Carabidae species composition of the four areas on Mt. Karatepa (Jaccard/Chekanovsky-Sørensen indices)

\begin{tabular}{lcccc}
\hline \multicolumn{1}{c}{ Sites } & Yul-say & Taxtaqoracha & Ettiuyli-say & Agalik-say \\
\hline Yul-say (1221 m a. s. 1.) & - & 0.27 & 0.27 & 0.39 \\
Taxtaqoracha(1550 m a. s. 1.) & 0.16 & - & 0.21 & 0.22 \\
Ettiuyli-say (1059 m a. s. 1.) & 0.08 & 0.06 & - & 0.28 \\
Agalik-say(1070 m a. s. 1.) & 0.17 & 0.12 & 0.09 & - \\
\hline
\end{tabular}

Diversity in the Chakilkalyan Mountains. 34 species of ground beetles belonging to 7 subfamilies and 21 genera were identified in the Chakikalyan Mountains (Table 4). The smallest diversity was noted at the highest Sariduqon site (6 species), where the bulk of the material is
Eocarterus chodshenticus. An interesting fact is that this species was not recorded in other areas of the Chakilkalyan Mountains, although in the Karatepa Mountains it was found in all the studied areas. The greatest variety of ground beetles was found in the areas Qumbel-say (18 species) and Yalpoqtepa (17 species). Although these areas are similar in species diversity, they differ significantly in altitude above sea level, and this probably results in a high difference in species composition (only 8 common species). On the Yalpoqtepa site, there are numerous species common in agrocenoses - Harpalus distinguendus, H. rufipes, Broscus asiaticus, Poecilus liosomus. The species Calosoma auropunctatum dsungaricum, Carenochyrus titanus, Harpalus griseus and Asaphidion flavicorne identified in this area were recorded neither in other areas of Chakhalkalyan nor in the Karatepa Mountains.

Table 4

Diversity and abundance of Carabidae in five mountain areas on Mt. Chakilkalyan

\begin{tabular}{|c|c|c|c|c|c|c|c|}
\hline \multirow[b]{2}{*}{ Species } & \multicolumn{5}{|c|}{ Montane habitat types } & \multirow[b]{2}{*}{ Total } & \multirow[b]{2}{*}{$\begin{array}{c}\text { Share } \\
\text { of species, } \%\end{array}$} \\
\hline & $\begin{array}{c}\text { Yalpoqtepa } \\
\text { (agrocenoses) }(890 \mathrm{~m} \\
\text { a. s. l.) }\end{array}$ & $\begin{array}{l}\text { Qumbel-say } \\
\text { (1480 ma.s. 1.) }\end{array}$ & $\begin{array}{c}\text { Kamanga-ron-say } \\
\text { (1300 ma.s. 1.) }\end{array}$ & $\begin{array}{c}\text { Sariduqon } \\
\text { (2350 ma.s. 1.) }\end{array}$ & $\begin{array}{l}\text { Hazrat Bashir } \\
\text { (1225 ma. s. 1.) }\end{array}$ & & \\
\hline Acinopus laevigatus & 1 & 3 & 1 & - & 3 & 8 & 3.8 \\
\hline Amara similata & - & 2 & - & - & - & 2 & 1.0 \\
\hline A. aenea & 3 & 10 & - & - & 2 & 15 & 7.2 \\
\hline Anchomenus dorsalis & 3 & 16 & 1 & 1 & 3 & 24 & 11.5 \\
\hline Asaphidion flavicorne & 3 & - & - & - & - & 3 & 1.4 \\
\hline Bembidion luridicorne & 5 & - & - & - & - & 5 & 2.4 \\
\hline B. piceocyaneum & - & 2 & - & - & - & 2 & 1.0 \\
\hline B. saxatile flavipalpe & - & 3 & - & - & - & 3 & 1.4 \\
\hline Brachinus explodens & - & 1 & - & - & 3 & 4 & 1.9 \\
\hline Broscus asiaticus & 7 & - & 1 & - & & 8 & 3.8 \\
\hline B. punctatus & - & - & 1 & - & & 1 & 0.5 \\
\hline Calathus ambigums & 1 & 3 & 2 & - & - & 6 & 2.8 \\
\hline C.peltatus & - & 1 & & - & - & 1 & 0.5 \\
\hline C. melanocephalus & - & 1 & 1 & - & - & 2 & 1.0 \\
\hline Calosoma auropunctatum dsungaricum & 5 & - & - & - & - & 5 & 2.4 \\
\hline Carenochyrus titanus & 4 & - & - & - & - & 4 & 1.9 \\
\hline Chlaenius festivus & - & - & - & - & 1 & 1 & 0.5 \\
\hline C. flavicornis & 2 & - & - & - & & 2 & 1.0 \\
\hline C. extensus & - & 17 & - & 1 & 2 & 20 & 9.6 \\
\hline Dixus eremita & - & - & - & 1 & 7 & 8 & 3.8 \\
\hline Dolichus halensis & 1 & 9 & - & - & 1 & 11 & 5.3 \\
\hline Eocarterus chodshenticus & - & - & - & 7 & - & 7 & 3.3 \\
\hline Harpalus distinguendus & 12 & 1 & 1 & - & - & 14 & 6.7 \\
\hline H. griseus & 2 & & - & - & & 2 & 1.0 \\
\hline H. rubripes & - & 4 & - & - & & 4 & 1.9 \\
\hline H. rufipes & 11 & 5 & 1 & 1 & 2 & 20 & 9.6 \\
\hline Nebria psammophila & - & 4 & - & - & - & 4 & 1.9 \\
\hline Poecilus cupreus & 3 & & - & - & - & 3 & 1.4 \\
\hline P. liosomus & 6 & 1 & - & - & - & 7 & 3.3 \\
\hline Pterostichus niger & 1 & - & - & - & - & 1 & 0.5 \\
\hline Scarites basiplicatus & - & - & 2 & - & - & 2 & 1.0 \\
\hline S. terricola & - & - & - & - & 5 & 5 & 2.4 \\
\hline Stenolophus abdominalis persicus & - & 1 & - & - & 1 & 2 & 0.9 \\
\hline Trechus quadristriatus & - & - & - & 2 & 1 & 3 & 1.4 \\
\hline Number of individuals & 70 & 84 & 11 & 13 & 31 & 209 & 100.00 \\
\hline Number of species & 17 & 18 & 9 & 6 & 12 & 34 & - \\
\hline Species richness, Dmg & 3.77 & 3.84 & 3.34 & 1.95 & 3.2 & 6.18 & - \\
\hline Diversity indicator Shannon, $\mathrm{H}$ & 2.56 & 2.44 & 2.15 & 1.41 & 2.28 & 3.15 & - \\
\hline Berger-Parker dominance index, $\mathrm{d}$ & 0.17 & 0.20 & 0.18 & 0.54 & 0.23 & 0.11 & - \\
\hline
\end{tabular}

On the Qumbel-say site, the most numerous are Chlaenius extensus, Anchomenus dorsalis, and Amara aenea. The only research point, located on the southern slope of Chakilkalyan, Hazrat Bashir is characterized by the same species that are common on the northern slope. However, there are some species that have been recorded only in this area (Chlaenius festivus and Scarites terricola). Dixus eremita and Scarites terricola are relatively abundant in this zone.

In general, only Anchomenus dorsalis and Harpalus rufipes were recorded in all sites studied. In the complex of ground beetles of the Chakilkalyan Mountains, the dominant species are Anchomenus dorsalis (11.5\%), Harpalus rufipes (9.6\%) and Chlaenius extensus (9.6\%) (Table 4).

Although the number of individuals collected from the Chakilkalyan Mountains is not very large, we tried to analyze the coefficients of similarity between different study points (Table 5). The value of the Jaccard index varied $0.10-0.38$, which means the minimum similarity of the studied territories. Moreover, the Chekanovsky-Sørensen index varied 0.12 0.50 . However, the Sariduqon and Hazrat Bashir sites are the most similar (Jaccard coefficient 0.38 ).

In general, the species diversity of the ground beetle fauna of the Chakilkalyan and Karatepa mountains is very close. In our collections, the number of species identified in each territory is the same ( 34 species each), of which 19 species are characteristic of both territories. However, a comparison of different indices of species richness shows that the species richness of the biocenoses of the Chakilkalyan Mountains is slightly higher in comparison with the biocenoses of the Karatepa Mountains (Table 6). However, the measures of dominance, that is, the proportion of dominant species, is higher in the community of the Karatepa Mountains, which means a low levelling and diversity. Furthermore, the similarity of the 
communities of the two mountains is insignificant (Chekanovsky-Sørensen coefficient -0.112 , Jaccard coefficient -0.39 ).

\section{Table 5}

The similarity of the Carabidae species composition of the five areas on Mt. Chakilkalyan (Jaccard/Chekanovsky-Sørensen indices)

\begin{tabular}{lccccc}
\hline \multicolumn{1}{c}{ Sites } & Yalpoqtepa & $\begin{array}{c}\text { Qumbel- } \\
\text { say }\end{array}$ & $\begin{array}{c}\text { Kamangaron- } \\
\text { say }\end{array}$ & Sariduqon & $\begin{array}{c}\text { Hazrat } \\
\text { Bashir }\end{array}$ \\
\hline $\begin{array}{l}\text { Yalpoqtepa } \\
\text { (agrosenoses) }(890\end{array}$ & - & 0.26 & 0.30 & 0.10 & 0.21 \\
$\begin{array}{l}\text { ma. s. 1.) } \\
\begin{array}{l}\text { Qumbel-say } \\
(1480 \text { ma. s. 1.) }\end{array}\end{array}$ & 0.22 & - & 0.29 & 0.14 & 0.36 \\
$\begin{array}{l}\text { Kamangaron-say } \\
(1300 \text { ma. s. } 1 .)\end{array}$ & 0.22 & 0.19 & - & 0.16 & 0.17 \\
$\begin{array}{l}\text { Sariduqon } \\
(2350 \text { ma. s. } 1 .)\end{array}$ & 0.14 & 0.12 & 0.50 & - & 0.38 \\
$\begin{array}{l}\text { Hazrat Bashir } \\
(1225 \text { ma. s. 1.) }\end{array}$ & 0.24 & 0.21 & 0.43 & 0.27 & - \\
\hline
\end{tabular}

Table 6

Assessment of the ecological diversity of the ground beetle fauna of the Chakilkalyan and Karatepa mountains

\begin{tabular}{lcc}
\hline \multicolumn{1}{c}{ Indices } & Chakilkalyan Mountains & Karatepa Mountains \\
\hline & Species richness indices \\
Margalef Index: & 6.18 & 5.51 \\
Shannon Index: & 3.15 & 2.79 \\
Menhinick Index: & 2.35 & 1.70 \\
Shannon Alignment: & 0.89 & 0.79 \\
\multicolumn{3}{c}{ Measures of dominance } \\
Simpson Index: & 0.052 & 0.083 \\
Berger Parker Index: & 0.115 & 0.148 \\
\multicolumn{3}{c}{ Chekanovsky-Sørensen coefficient } \\
Jaccard coefficient & Similarity factors & \\
\hline
\end{tabular}

\section{Discussion}

Our primary data on the fauna of ground beetles of the Karatepa and Chakilkalyan mountains of the Zarafshan Range did not show a very high biodiversity. The fauna of ground beetles in the eastern part of the Zarafshan Range has a fairly high diversity (204 species), while the neighbouring Turkestan and Alai ranges located in Tajikistan include 145 species, the Eastern Pamirs - 47 species (Mikhaylov, 1998). In general, the data obtained on the fauna of ground beetles in different mountain ranges of Asia are ambiguous. So, according to the data of Dudko et al. (2010), the ridges located in the Altai (Russia) differ significantly in the diversity of ground beetles (the Shapshal Ridge includes 23 species, the Chigachev Ridge 32 species, the Saylyugem Ridge 46 species, the South Chuya Ridge 48 species, Southern Altai Ridge 24 species). In the Chinese Changbai Mountains, which coincide in altitude range with our mountains, but is a forest ecosystem, the diversity of ground beetle fauna was 47 species (Zou et al., 2014), and in the Beijing Mountains, 23 species (Warren-Thomas et al., 2014).

The diversity of the ground beetle fauna largely depends on the vegetation cover and the location of the area above sea level. Thus, in mixed mountain forests, the ground beetle fauna is richer than that of pine or oak forests (Finch, 2005; Warren-Thomas et al., 2014). The species richness of the carabid complex decreased with increasing altitude (Hanski \& Hammond 1986; Maveety et al., 2011; Dudko et al., 2010). Besides, agrocenoses located in mountainous regions are richer in species composition of ground beetles than natural cenoses. Our results also confirm this. However, the dominance measures disagree with some volatile data (Warren-Thomas et al., 2014), where the share of the most abundant species in different mountain biotopes ranged $42-64 \%$.

Ground beetles are highly sensitive to environmental changes, showing strong habitat specificity and low rates of distribution between sites (Work et al., 2008; Koivula, 2011). Apparently, this can also be the reason for the low coefficients of similarity of the ground beetle fauna in different parts of the mountain territories in our studies. In our studies, the main part of the ground beetle fauna of the studied mountains was represented by species of the subfamily Harpalinae. In addition to adapting to the soil environment, Harpalinae also have morphological adaptations to life on plants (Ober, 2003). In addition, they are also adapted to feed on seeds, mainly the seeds of herbaceous plants (Honek et al., 2003). Thus, this ability can lead to the presence of a large number of Harpalinae species in the mountains (Qodri et al., 2016).

\section{Conclusion}

In the course of our initial research in the Chakilkalyan and Karatepa mountains of the Zarafshan Ridge, 49 species of ground beetles were recorded belonging to 31 genera, 16 tribes and 8 subfamilies. The most representative was the subfamily Harpalinae (32 species from 20 genera $(65.3 \%)$. The Trechinae subfamily included five species from three genera $(10.2 \%)$, the Scaritinae subfamily - four species from two genera $(8.2 \%)$, the Carabinae subfamily - three species from two genera $(6.1 \%)$, the Broscinae subfamily - two species from the same genus $(4.1 \%)$. The subfamilies Brachininae, Cicindelinae and Nebriinae are represented by one species $(2.0 \%$ each).

In the Karatepa Mountains, 34 species from 23 genera have been identified, and in the Chakilkalyan Mountains, 34 species from 21 genera. These two mountains have 19 common types and 15 unique ones. In the Karatepa Mountains, the dominant species are Zabrus morio, Eocarterus chodshenticus, Amara aenea, and Acinopus laevigatus, and the subdominant ones are Brachinus explodens, Calathus ambiguus, and Poecilus longiventris. In the Chakilkalyan Mountains, Anchomenus dorsalis, Harpalus rufipes, and Chlaenius extensus are dominant, while Amara aenea, Harpalus distinguendus, Dolichus halensis turned out to be subdominant. However, at different sites, the dominant species vary. The variation in dominant and subdominant species in different parts of the mountains is explained both by differences in food resources and by microclimatic conditions corresponding to the ecological characteristics of a particular taxon.

Different areas of both mountains differ significantly in the diversity of ground beetle fauna. In both mountains, the lowest diversity was noted at the highest altitudes (Sariduqon and Takhtakoracha). The similarity of the fauna of different parts of both mountains, on average, was low. Thus, in four areas of the Karatepa Mountains, the average value of the Jaccard and Chekanovsky-Sörensen indices was 0.27 and 0.11 , and in five areas of the Chakilkalyan Mountains -0.24 and 0.25 . And the similarity of the communities of the two mountains with each other was also insignificant (Chekanovsky-Serensen coefficient-0.112, Jaccard coefficient - 0.39).

The presented ecological-faunistic study of ground beetles of two mountains of the Zarafshan ridge is of a preliminary nature. These studies will be continued and expanded.

We express our sincere gratitude to R. Dudko (Novosibirsk) for help in identifying species and E. Abdullaev (Samarkand) for useful advice in writing this article.

\section{References}

Alimdjanov, R. A., \& Bronshteyn, T. G. (1956). Bespozvonochnye jivotnye Zarafshanskoj doliny [Invertebrate animals of the Zarafshan valley]. Publishing House of the Academy of Sciences of the UzSSR, Samarkand (in Russian).

Barber, H. S. (1931). Traps for cave-inhabiting insects. Journal of the Elisha Mitchell Scientific Society, 46(2), 259-266.

Bekmetova, Z. K. (1991). Rol' hischnykh zhuzhelits (Coleoptera, Carabidae) v hlopkovo-liutsemovykh sevooboratakh severo-vostochnykh rajonov khlopkosejanija [Role of carnivorous ground beetles (Coleoptera, Carabidae) in cotton-alfalfa crop rotations of north-eastern cotton growing regions]. VIZR, Leningrad (in Russian).

Bell, A. J., Phillips, I. D., Nielsen, S. E., \& Spence, J. R. (2017). Species traits modify the species area relationship in ground-beetle (Coleoptera: Carabidae) assemblages on islands in a boreal lake. PLoS One, 12(12), e0190174.

Dadamirzaev, A. (1978). K faune i ekologii zhuzhelits (Coleoptera, Carabidae) Tashkentskoj oblasti [To the fauna and ecology of ground beetles (Coleoptera, Carabidae) of the Tashkent region]. In: Ecology of vertebrates and invertebrates in Uzbekistan. Fan, Tashkent (in Russian). 
Dudko, R. Y., Matalin, A. V., \& Fedorenko, D. N. (2010). Fauna zhuzhelits (Coleoptera, Carabidae) Yugo-Vostochnogo Altaya [Fauna of ground beetles (Coleoptera, Carabidae) of South-Eastern Altai]. Zoological Journal, 89(11), $1312-1330$ (in Russian).

Dunaev, E. A. (1997). Metody ekologo-entomologicheskikh issledovanij [Methods of ecological and entomological research]. MosgorSYUN, Moskow (in Russian).

Dzhumaev, T. (1989). Gory Uzbekistana [Mountains of Uzbekistan]. Mehnat, Tashkent (in Russian).

Finch, O. D. (2005). Evaluation of mature conifer plantations as secondary habitat for epigeic forest arthropods (Coleoptera: Carabidae; Araneae). Forest Ecology and Management, 204, 21-34.

Hanski, I, \& Hammond, P. (1986). Assemblages of carrion and dung Staphylinidae in tropical rain forests in Sarawak, Borneo. Annales Entomologici Fennici, 52, $1-19$

Heydemann, B. (1955). Carabiden der Kulturfelder als ekologische Indikatoren. In: Berber die 7 Wander Sammlung Deutscher Entomologen. Berlin. Pp. 172-185.

Honek, A., Martinkova, Z., \& Jarosik, V. (2003). Ground beetles (Carabidae) as seed predators. European Journal of Entomology, 100(4), 531-544.

Kabak, I. I. (2008). Zhuzhelitsy roda Carabus L. (Coleoptera, Carabidae) Tian-Shania [Ground beetles of the genus Carabus L. (Coleoptera, Carabidae) of the Tien Shan]. Rizo-Pechat, Saint Petersburg (in Russian).

Kabak, I. I. (2015). To the distribution of some ground-beetles (Coleoptera, Carabidae) in Kazakhstan and Middle Asia. Euroasian Entomological Journal, 14(1), 14-20.

Kabak, I. I., Muller-Motzfeld, G., \& Milko, D.A. (2016). Distribution of some ground-beetle species (Coleoptera, Carabidae) in Kirgizia. Euorasian Entomological Journal, 15(1), 12-16.

Karpova, V. E. (1992). Effektivnost otlova zhuzhelits (Coleoptera, Carabidae) lovushkami Barbera raznogo tipa [The efficiency of trapping ground beetles (Coleoptera, Carabidae) by various types of Barber traps]. Biological Sciences, 5, 84-88 (in Russian)

Kędzior, A., Szwalec, A., Mundała, A., \& Skalski, T. (2020). Ground beetle (Coleoptera, Carabidae) life history traits as indicators of habitat recovering processes in postindustrial areas. Ecological Engineering, 142, 105615.

Khalimov, F. Z. (2008). Agrocenozlarda Staphylinidae va Carabidae oilasiga mansub jmrtkich kungizlar sonining mavsumij uzgarishlari [Seasonal changes in the number of predatory beetles belonging to the family Staphylinidae and Carabidae in agrocenoses]. Scientific Research Bulletin of Samarkand State University, 3, 59-62 (in Uzbek).

Koivula, M. J. (2011). Useful model organisms, indicators, or both? Ground beetles (Coleoptera, Carabidae) reflecting environmental conditions. Zookeys, 100, 287-317.

Kotze, J., Brandmayr, P., Casale, A., Dauffy-Richard, E., Dekoninck, W., Koivula, M., Lovei, B., Mossakowski, D., Noordijk, J., Paarmann, W., Pizzoloto, R., Saska, P., Schwerk, A., Serrano, J., Szyszko, J., Palomares, A., Turin, H., Venn, S., Vermeulen, R., \& Zetto Brandmayr, T. (2011). Forty years of carabid beetle research in Europe - from taxonomy, biology, ecology and population studies to bioindication, habitat assessment and conservation. Zookeys, 100, 55-148.

Kryzhanovskij, O. L. (1965). Sostav i proiskhozhdenie nazemnoj fauny Srednei Azii (glavnym obrazom na materiale po zhestkokrylym) [Composition and origin of the terrestrial fauna of Central Asia (based chiefly on the beetles material)]. Nauka, Leningrad (in Russian).
Kryzhanovskij, O. L., Belousov, I. A., Kabak, I. I., Kataev, B. M., Makarov, K. V., \& Shilenkov, V. G. (1995). A checklist of the ground-beetles of Russia and adjacent lands (Insecta, Coleoptera, Carabidae). Pensoft, Sofia-Moscow.

Kryzhanovskij, O. L. (1994). New and poorly known Carabidae from North, Central and East Asia (Coleoptera). Zoosystematica Rossica, 3, 265-272.

Lorenz, W. (2005). Nomina Carabidarum - A directory of the scientific names of ground beetles (Insecta, Coleoptera "Geadephaga": Trachypachidae and Carabidae incl. Paussinae, Cicindelinae, Rhysodinae). Lorenz Educational Pub, Tutzing.

Maveety, S. A., Browne, R. A., \& Erwin, T. L. (2011). Carabidae diversity along an altitudinal gradient in a Peruvian cloud forest (Coleoptera). ZooKeys, 147 , 651-666.

Mihaylov, V. A. (1995). Novyiy vid roda Bembidion Latr. (Coleoptera, Carabidae) iz Severnogo Tadjikistana [A new species of the genus Bembidion Latr. (Coleoptera, Carabidae) from Northern Tajikistan]. Bulletin of the Kharkov Entomological Society, 3(1), 66-67 (in Russian).

Mihaylov, V. A. (1998). Zhuki-zhuzhelitsi (Coleoptera, Carabidae) yugo-vostoka Sredney Azii (fauna, ekologiya, znacheniya v biotsenozakh) [Ground beetles (Coleoptera, Carabidae) of the southeast of Central Asia (fauna, ecology, values in biocenoses)]. Leningrad (in Russian)

Ober, K. A. (2003). Arboreality and morphological evolution in ground beetles (Carabidae: Harpalinae): Testing the taxon pulse model. Evolution, 57(6), 1343-1358.

Qodri, A., Raffiudin, R., \& Noerdiito, W. (2016). Diversity and abundance of Carabidae and Staphylinidae (Insecta: Coleoptera) in four montane habitat types on Mt. Bawakaraeng, South Sulawesi. Hayati Journal of Biosciences, 23, 22

Schirmel, J., Blindow, I., \& Buchholz, S. (2012). Life-trait and functional diversity patterns of ground beetles and spiders along a coastal headland successional gradient. Basic and Applied Ecology, 13, 606-614.

Skalski, T., Gargasz, K., \& Laskowski, R. (2011). Does mixed diffused pollution decrease ground beetle diversity? Baltic Journal of Coleopterology, 11, 1-15.

Skalski, T., Kędzior, R., Kolbe, D., \& Knutelski, S. (2015). Ground beetles as indicators of heavy metal pollution in forests. Sylwan, 159, 905-911.

Skufin, K. V. (1949). K ekologii slepney Voronejskoy oblasti [On the ecology of horseflies of the Voronezh region]. Zoological Journal, 28(2), 145-156.

Stiling, P., \& Cornelissen, T. (2005). What makes a successful biocontrol agent? A metaanalysis of biological control agent performance. Biological Control, 34(3), 236-246.

Symondson, W. O., Sunderland, K. D., \& Greenstone, M. H. (2002). Can generalist predators be effective biocontrol agents? Annual Review of Entomology, 47(1), 561-594.

Warren-Thomas, E., Zou, Y., Dong, L., Yao, X., Yang, M., Zhang, X., Qin, Y., Liu, Y., Sang, W., \& Axmacher, J. (2014). Ground beetle assemblages in Beijing's new mountain forests. Forest Ecology and Management, 334, 369-376.

Work, T. T., Koivula, M., Klimaszewski, J., Langor, C., Spence, J. R., Sweeney, J, \& Hebert, C., (2008). Evaluation of carabid beetles as indicators of forest change in Canada. Canadian Entomologist, 140,393-414.

Zou, Y., Sang, W., Zhou, H., Huang, L., \& Axmacher, J. C. (2014). Altitudinal diversity patterns of ground beetles (Coleoptera: Carabidae) in the forests of Changbai Mountain, Northeast China. Insect Conservation and Diversity, 7(2), 161-171. 